\title{
An Attempt to Identify the Intestinal Receptor for the K88 Adhesin by Means of a Haemagglutination Inhibition Test using Glycoproteins and Fractions from Sow Colostrum
}

\author{
By R. A. GIBBONS, G. W. JONES AND R. SELLWOOD \\ Agricultural Research Council, Institute for Research on Animal Diseases, \\ Compton, Newbury RGI6 oNN, Berkshire
}

(Received I7 June 1974; revised 9 September 1974)

\begin{abstract}
SUMMARY
The K88 antigen of Escherichia coli specifically adheres to the piglet intestinal cell; a solution of this antigen agglutinates guinea-pig red cells at $4{ }^{\circ} \mathrm{C}$. The latter reaction was used as a model of the former, using inhibition of haemagglutination as an index of specific combination with the K88 adhesin. Inhibition was found with mucous glycoproteins and chemical modification of their heterosaccharide residues by mild acid hydrolysis, periodate oxidation or the Smith degradation procedure suggested that the terminal $\beta$-D-galactosyl structure in a heterosaccharide sidechain of a glycoprotein might combine specifically with the K88 adhesin and inhibit haemagglutination. One serum glycoprotein (fetuin), after exposure of its subterminal $\beta$-D-galactosyl residue, also inhibited haemagglutination, but high inhibitory activity was exhibited by some submaxillary glycoproteins in which this structure was absent or not prominent. It was concluded that in some cases inhibition of haemagglutination by glycoprotein was non-specific. No inhibition was found using glycosaminoglycans, glycogen or any simple sugar or glycoside. Sow colostrum was inhibitory but this was associated mainly with its $\gamma$-globulin fraction. Some inhibitory activity was traced to a colostral glycopeptide fraction of low molecular weight but the smaller colostral oligosaccharides were not inhibitory; the composition of these components in sow colostrum is reported.
\end{abstract}

\section{INTRODUCTION}

Most serotypes of Escherichia coli that cause diarrhoea in neonatal piglets produce a $\mathrm{K}$ antigen designated K88 (Sojka, I97I). Arbuckle (1970) showed that several strains belonging to K88-positive serotypes adhered to the mucosa of the piglet small intestine and Smith \& Linggood (1972) concluded that the ability of a strain to proliferate in the anterior small intestine was enhanced after the strain had acquired the capacity to produce K88 antigen. Jones \& Rutter (I972) demonstrated that the synthesis of K88 antigen by $E$. coli in the intestine of the piglet conferred adhesive properties on the bacterial cell that enabled K88positive $E$. coli to attach to and colonize the mucosa; its K88-negative mutant did not adhere and was virtually avirulent to conventional piglets. Thus an essential element in the pathogenic character of these bacteria for the neonatal piglet appears to be their ability (conferred by the presence of K88 antigen) to adhere to the mucosal surface of the small intestine and subsequently proliferate in this favourable location.

A solution of $\mathrm{K} 88$ antigen obtainable from K88-positive $E$. coli agglutinates guinea-pig red cells at $4{ }^{\circ} \mathrm{C}$ (Jones, 1972; Jones \& Rutter, 1974). The haemagglutinin cannot be sepa- 
rated from the $\mathrm{K} 88$ antigen. The haemagglutination reaction (HA), which is much easier to study than the adhesion of bacteria to the intestinal cell, ought to provide a convenient test system for the study of the important and specific interaction between host and pathogen. In particular, the inhibition of the haemagglutination reaction by substances of known structure - one of the techniques which has been so successful in elucidating the chemical structure of the human $\mathrm{ABO}$ and Lewis blood group receptors (Watkins \& Morgan, $1962 a, b$; Watkins, 1972) - could be used to reveal the chemical structural requirements for combination with $\mathrm{K} 88$, and by inference the structure of the receptor for $\mathrm{K} 88$ present in the intestinal cell wall of the susceptible piglet. However, K88-positive E. coli adhere to the porcine gut cell at $37^{\circ} \mathrm{C}$. Preliminary work has shown that this interaction occurs in vitro between bacteria and suspensions of pig intestinal brush borders (R. Sellwood, unpublished) and, unlike the HA, it is insensitive to temperature between 4 and $37^{\circ} \mathrm{C}$. Since HA only occurs at low temperatures the 'fit' for the guinea-pig red cell receptor and the K88 antigen is probably not as good as it is for the natural receptor.

Jones (1972) found that the contents of the small intestine of the germ-free colostrumdeprived piglet contained an HA inhibitor which had the properties of a glycoprotein or polysaccharide (heat resistance, stability to proteolytic enzymes, insolubility in chloroform/ methanol, and susceptibility to oxidation with periodate). Thus it seems reasonable to suppose that the structure in the cell membrane (of the piglet intestinal cell and of the guinea-pig red cell) with which $\mathrm{K} 88$ specifically combines is a glycoprotein; also that the determinant structure is likely to be at or near the terminal non-reducing ends of the heterosaccharide residue(s). Accordingly, the ability of selected glycoproteins to inhibit the HA reaction has been determined. The structures of the heterosaccharide residues of most of these glycoproteins are known and can be modified chemically in known, specific ways, giving a wide variety of structures whose inhibitory titres can be compared.

Included in these glycoproteins were two samples isolated from pig small intestine, which probably represent purified samples of the inhibitor which Jones (1972) originally described. Pigs have three genetically determined mucus glycoprotein structures, termed $\mathrm{H}, \mathrm{AH}$ and In (Chadwick, Smith, Annison \& Morgan, 1949; Aminoff, Morrow \& Zarafonetis, 1964); the relevant structures (similar to but not identical with those of the human blood-group substances) are given by Slomiany \& Meyer (1973) and Baig \& Aminoff (1973). The In phenotype has not been detected in the intestinal glycoprotein in this laboratory, but both $\mathrm{H}$ and AH samples have been examined separately. A number of simple sugars, some of their glycosides, two glycosaminoglycans and one polysaccharide have also been tested for HA inhibition.

The HA inhibition test could help to clarify another important aspect of the pathogenesis of neonatal diarrhoea in piglets. Although the colostral immunoglobulins are protective against the disease in the piglet (Kohler \& Bohl, 1966; Miniats, Mitchell \& Barnum, 1970; Wilson, Gyles \& Svendsen, I97I; Smith, 1972; Rutter \& Jones, 1973; Brandenburg \& Wilson, 1973), in other species the immunoglobulin fraction seems to be less important (Kenny, Weinert \& Gray, 1974) and substances in colostrum other than immunoglobulins may have an additional protective effect in the neonatal gut. Oligosaccharides in human colostrum have the same sugar sequence as the epithelial glycoprotein heterosaccharide residues and the surface glycolipid antigens of some cells (Hakomori \& Jeanloz, 1970; Huang, 1971; Kobata \& Ginsberg, 1972 a, b), and milk oligosaccharides appear important in the protection of the human baby (Schönfeld, 1927; Gyorgy, Norris \& Rose, 1954; Grimmonprez, 1971). There is the possibility, therefore, that non-lactose colostral saccharides react with the $\mathrm{K} 88$ adhesin and thus reduce the adhesive ability of K88-positive E. coli, rendering 
them less able to colonize the small intestine. Milk oligosaccharides are to be found in every species of mammal examined, in marsupials and even in monotremes (Messer \& Kerry, 1973). While the human oligosaccharides have been well investigated (Kuhn \& Gauhe, I962 $a, b$, I965; Kobata \& Ginsberg, I972a,b), those from other mammals are less well characterized. Consequently we have carried out a preliminary chemical characterization of sow colostrum paying particular attention to the oligosaccharide fraction and the ability of its components to inhibit K88-mediated HA.

\section{METHODS}

Haemagglutination-reaction inhibition test. Four to eight haemagglutinating doses of K88 haemagglutinin in $25 \mu \mathrm{l}$ vols. were incubated on ice for I $5 \mathrm{~min}$ with equal volumes of serial twofold dilutions of test substance. Guinea-pig red cell suspension ( $25 \mu 1$ vols.; $3 \%$, $\mathrm{v} / \mathrm{v}$ ) was then added and the mixture incubated at $4{ }^{\circ} \mathrm{C}$ for $2 \mathrm{~h}$ (Jones, I972; Jones \& Rutter, I974). The HA inhibition titre was taken as the highest dilution of test material that inhibited haemagglutination.

Precipitin reaction. This was in the immunodiffusion medium of Jones \& Rutter (1972) with whole sow colostrum and their partially purified K88 antigen. The density of the precipitin lines was assessed by eye after 7 days at $4{ }^{\circ} \mathrm{C}$.

Glycoproteins. Submaxillary glycoproteins from sheep (OSM), pig (PSM) and cattle (BSM) were prepared by the method of Heimer \& Meyer (1956). PSM was also prepared as described by Gibbons (1963). Human blood-group substances were prepared from ovarian cyst mucin (Gibbons, Morgan \& Gibbons, I955). Intestinal glycoprotein from the pig was isolated as described by Gibbons, Dixon \& Pocock (1973). Bovine cervical mucus glycoprotein was the sample isolated from the oestrous secretion by Gibbons \& Sellwood (I973). Fetuin and $\alpha_{1}$ acid glycoprotein were commercial samples (Koch-Light Laboratories Ltd, Colnbrook, Buckinghamshire).

Glycosaminoglycans. Heparin was from $\mathrm{BDH}$, and hyaluronic and chondroitin sulphuric acids from Sigma.

Glycogen. This was a commercial sample from Sigma.

Chemical modification of the glycoproteins. (i) By mild acid hydrolysis. The submaxillary gland glycoproteins $(0.25 \%)$ were hydrolysed in sulphuric acid (0.I M) for $2 \mathrm{~h}$ at $80{ }^{\circ} \mathrm{C}$ to remove the major portion of the neuraminic acid and also, where present, much of the fucose. Fetuin was hydrolysed for I h only; the neuraminic acid in this glycoprotein is more readily removed.

(ii) By alkali-borohydride treatment (Bertolini \& Pigman, 1970). The reaction mixture was then neutralized, freeze-dried and passed down a column $(\mathrm{I} \times 100 \mathrm{~cm})$ of Sephadex $\mathrm{G}_{50}$ (Pharmacia) at room temperature. The fractions containing carbohydrate were passed down a column ( $\cdot 5 \times 60 \mathrm{~cm}$ ) of Biogel P2 (Biorad Laboratories Ltd, Bromley, Kent). Chloroformsaturated water was used as the eluant.

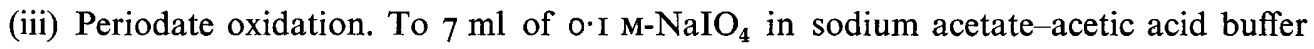
( $\mathrm{I} \mathrm{M}, \mathrm{pH} \mathrm{3.5)} \mathrm{were} \mathrm{added} 50 \mathrm{mg}$ of the glycoprotein dissolved in $28 \mathrm{ml}$ water. After $3 \mathrm{~h}$ in the dark at $4{ }^{\circ} \mathrm{C}, 0.35 \mathrm{ml}$ of $2 \%(\mathrm{v} / \mathrm{v})$ aqueous ethylene glycol was added. The solution was dialysed against running distilled water for $24 \mathrm{~h}$ at $4{ }^{\circ} \mathrm{C}$; a sample was withdrawn and freeze-dried to ascertain the concentration of the oxidized glycoprotein.

(iv) Periodate oxidation/borohydride reduction and (v) Smith degradation (Smith \& Unrau, 1959). The periodate oxidation stage was carried out as already described except that the oxidation was allowed to go to completion $(\mathrm{I} 7 \mathrm{~h})$. The volume of indiffusible material was adjusted to $50 \mathrm{ml}$ and solid sodium borohydride $(0.33 \mathrm{~g})$ added at $4{ }^{\circ} \mathrm{C}$ with stirring 
whilst $2 \mathrm{M}-\mathrm{HCl}$ was added by a $\mathrm{pH}$-stat (Metrohm $\mathrm{Ltd}, \mathrm{CH}-9100$, Herisau, Switzerland) to maintain the $\mathrm{pH}$ at 8.0 . Sodium borohydride solution $(0 \cdot 2 \mathrm{M}$ in $50 \%, \mathrm{v} / \mathrm{v}$, aqueous ethanol containing $0.0 \mathrm{I} \mathrm{M}-\mathrm{NaOH}$ ) was added at a rate of $5 \mathrm{ml} / \mathrm{h}$ continuously for $18 \mathrm{~h}$ at $4{ }^{\circ} \mathrm{C}$ with $\mathrm{pH}$-stat control to $\mathrm{pH} 8$. At this stage one of two courses was followed. For method (iv) (borohydride-reduced material), the $\mathrm{pH}$ was brought to $5^{\circ} \mathrm{\circ}$. For (v), where it was desired to cleave the oligosaccharide residues at the points of periodate attack using a modified Smith degradation, the solution was adjusted to $\mathrm{pH} \mathrm{I} \cdot 2$ and held at $65^{\circ} \mathrm{C}$ for $2 \cdot 5 \mathrm{~h}$. Subsequently, for both procedures (iv) and (v), the reaction mixture was freeze-dried, dissolved in a small quantity of water, dialysed at $4{ }^{\circ} \mathrm{C}$ to zero ionic strength, and freeze-dried.

The scale of the reactions was varied as circumstances required, but the proportions were maintained as closely as possible to those given above.

Sow colostrum. Colostrum was collected manually from sows up to $6 \mathrm{~h}$ post partum and stored at $-20^{\circ} \mathrm{C}$; all animals were from the Institute's minimal disease herd. When required, quantities of about $200 \mathrm{ml}$ were thawed and centrifuged at approx. $40000 \mathrm{~g}$ for $4 \mathrm{~h}$ to separate the cream and the casein from the colostral whey. Portions of whey $(25 \mathrm{ml})$ were fractionated at $4{ }^{\circ} \mathrm{C}$ on a column $(5 \times 100 \mathrm{~cm})$ of Sephadex G200 eluting with $0.05 \mathrm{M}$-sodium acetate-acetic acid buffer, $\mathrm{pH} 6.5$, containing $0 . \mathrm{I} \%$ sodium azide. The eluate was monitored at $280 \mathrm{~nm}$ and appropriate fractions were pooled. Each fraction was examined by polyacrylamide gel electrophoresis. The retarded fractions ( $\mathrm{E}$ and $\mathrm{F}$, see later), richer in carbohydrate material, were refractionated on Sephadex G25 columns $(2 \times 100 \mathrm{~cm})$ eluting with chloroform-saturated water. Fractions from this column were further purified by fractionation on Biogel P2. Column eluates were in these latter two cases monitored for protein (extinction at $230 \mathrm{~nm}$ ), sugars (Yemm \& Willis, 1954) and neuraminic acid (Svennerholm, 1957).

The yield of oligosaccharide from colostral whey could be improved by using the method of Ohman \& Hygstedt (1968), although the protein fraction is lost. The carbohydraterich aqueous layer was concentrated under reduced pressure and fractionated as above, substituting Biogel $\mathrm{P}_{4}$ for $\mathbf{P} 2$.

Paper chromatography. Descending chromatograms (Whatman No. 4) irrigated with the single-phase system ethyl acetate-acetic acid-pyridine-water (Fischer \& Nebel, I955) were run. Spots were visualized using silver nitrate in ethanolic potassium hydroxide (Heimer, I957), or periodate/permanganate (Wolfrom \& Miller, I956).

\section{RESULTS}

Haemagglutination-reaction inhibition tests with glycoproteins, glycosaminoglycans and various carbohydrates

The inhibition of haemagglutination by all the epithelial glycoproteins examined (Table I) confirmed the earlier observation of Jones (1972). The structurally different serum glycoproteins and the markedly different glycosaminoglycans were not inhibitory. However, the lack of inhibition by monosaccharides commonly found as constituent parts of mammalian glycoproteins, or by their $\alpha$ - and $\beta$-methyl glycosides, suggests that the inhibitor site is probably larger than a single sugar residue.

Haemagglutination-reaction inhibition tests with chemically modified glycoproteins. Human $\mathrm{A}$ and $\mathrm{H}$ substances are the best characterized of the more complex glycoproteins, to which pig intestinal glycoprotein is probably similar (Table 2). Periodate oxidation of human $\mathrm{A}$ and $\mathrm{H}$ substances, which destroys the terminal sugar residues responsible for serological activity, also destroyed their inhibitory activity. The subsequent reduction and 


\section{Table I. Haemagglutination inhibition by glycoproteins and related compounds*}

Tabulated values are the lowest concentrations $(\mu \mathrm{g} / \mathrm{ml})$ which inhibited agglutination at $4{ }^{\circ} \mathrm{C}$ of an equal volume of a $3 \%$ suspension of guinea-pig red cells by 4 to 8 haemagglutinating doses of soluble K88 antigen from $E$. coli.

$\begin{array}{lr}\text { Epithelial glycoproteins } & \\ \text { Human H substance } & 150 \\ \text { Human A substance } & 375 \\ \text { Porcine intestinal glycoprotein - A active } & 200 \\ \text { Porcine intestinal glycoprotein - H active } & 200 \\ \text { Bovine cervical glycoprotein } & 940 \\ \text { Porcine submaxillary glycoprotein } & 20 \\ \text { Bovine submaxillary glycoprotein } & 200 \\ \text { Ovine submaxillary glycoprotein } & 50 \\ \text { Glycosaminoglycans } & \\ \text { Heparin } & \\ \text { Chondroitin sulphuric acid (A+D) } \\ \text { Hyaluronic acid } \\ \text { Serum glycoproteins } \\ \text { Fetuin } \\ \left.\alpha_{1} \text { Acid glycoprotein }\right\}\end{array}$

* The following sugars and methyl glycosides were all non-inhibitory at $5 \mathrm{mg} / \mathrm{ml}$ : D-arabinose, D-xylose, D-ribose (BDH), D-galactose (Sigma), and its $\alpha$ and $\beta$ methyl glycosides, D-mannose (BDH), L-rhamnose, L-fucose and its $\alpha$ methyl glycoside, $N$-acetyl- or $N$-glycollyl neuraminic acid (Sigma), 2-deoxy-2-acetamido$\mathrm{D}$-glucose or D-galactose (Koch Light) and the $\alpha$ and $\beta$ methyl glycosides of both the $N$-acetylhexosamines, lactose, maltose, melibiose, trehalose, sucrose, cellobiose, raffinose and glycogen (BDH).

\section{Table 2. Chemical analysis of glycoproteins}

Hexosamine is expressed as the free base, and neuraminic acid as the $N$-acetyl compound except in the case of porcine submaxillary glycoprotein where an appropriate correction factor (Gibbons, I963), is used to convert to the $N$-glycollyl derivative actually present. Analytical methods were as follows. Hexose: Yemm \&Willis (1954), using galactose as standard. Hexosamine: Rondle \& Morgan (1955), after $16 \mathrm{~h}$ at $100{ }^{\circ} \mathrm{C}$ in $0.5 \mathrm{~N}-\mathrm{HCl}$. Neuraminic acid: Warren (I959), after $2 \mathrm{~h}$ at $80^{\circ} \mathrm{C}$ in $0 \cdot 0 \mathrm{r} \mathrm{N}-\mathrm{H}_{2} \mathrm{SO}_{4}$. Fucose: Gibbons (1955).

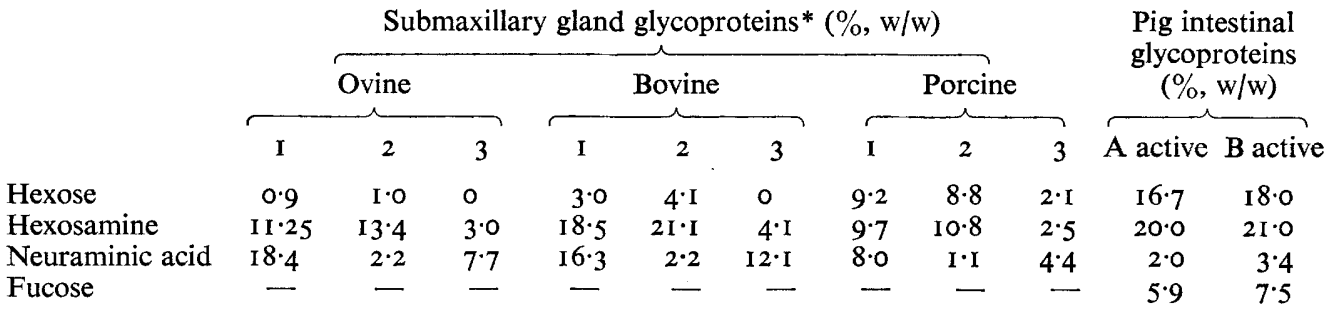

* Analysis of (I) undegraded glycoprotein; (2) glycoprotein after treatment with o. I N- $\mathrm{H}_{2} \mathrm{SO}_{4}$ for $2 \mathrm{~h}$ at $80^{\circ} \mathrm{C}$ and dialysis; (3) glycoprotein after periodate oxidation, reduction with sodium borohydride and dialysis.

removal of the terminal polyhydric alcohols resulted in a re-expression of some HA inhibitory activity (Table 3) although blood group activity remained lost. The results of chemical modification of the structurally simpler submaxillary gland glycoproteins (Tables 2 and 3 ) are difficult to interpret, one reason being that no treatment completely eliminated HA inhibition unless the molecule was extensively fragmented. Degradation of BSM and PSM by alkali in the presence of borohydride generates a number of small oligosaccharides, usually terminating in $\mathrm{N}$-acetylgalactitol (McGuire, 1970). A fraction was isolated in poor yield 


\section{Table 3. Haemagglutination inhibition by chemically modified glycoproteins}

\begin{tabular}{|c|c|c|}
\hline Human A substance & $\begin{array}{l}\text { Oxidized with periodate for } 3 \mathrm{~h} \text { (iii) } \\
\text { Oxidized with periodate for } \mathrm{I} 7 \mathrm{~h} \text {, reduced } \\
\text { and hydrolysed (v) }\end{array}$ & $\begin{array}{r}>5000 \\
200\end{array}$ \\
\hline Human $\mathrm{H}$ substance & $\begin{array}{l}\text { Oxidized with periodate for } 3 \mathrm{~h} \text { (iii) } \\
\text { Oxidized with periodate for } \mathrm{I} 7 \mathrm{~h} \text {, reduced } \\
\text { and hydrolysed }(\mathrm{v})\end{array}$ & $\begin{array}{r}>5000 \\
1000\end{array}$ \\
\hline Porcine submaxillary glycoprotein & $\begin{array}{l}\text { Control (heated } 2 \mathrm{~h} \text { at } 80{ }^{\circ} \mathrm{C} \text { at } \mathrm{pH} 7 \text { ) } \\
\text { After removal of neuraminic acid (i) } \\
\text { After oxidation with periodate for } 17 \mathrm{~h} \\
\text { and reduction with sodium borohydride (iv) } \\
\text { After alkali borohydride treatment (ii) } \\
\text { Peptide portion } \\
\text { Heterosaccharide portion }\end{array}$ & $\begin{array}{r}50 \\
100 \\
375 \\
>50000 \\
>50000\end{array}$ \\
\hline Bovine submaxillary glycoprotein & $\begin{array}{l}\text { Control (heated } 2 \mathrm{~h} \text { at } 80^{\circ} \mathrm{C} \text { at } \mathrm{pH} 7 \text { ) } \\
\text { After removal of neuraminic acid (i) } \\
\text { After alkali borohydride treatment (ii) } \\
\text { Peptide portion } \\
\text { Heterosaccharide portion }\end{array}$ & $\begin{array}{r}375 \\
1000 \\
15000 \\
>5000\end{array}$ \\
\hline Ovine submaxillary glycoprotein & $\begin{array}{l}\text { Control (heated at } 80^{\circ} \mathrm{C} \text { and } \mathrm{pH} 7 \text { ) } \\
\text { After removal of neuraminic acid (i) } \\
\text { After oxidation with periodate for } \mathrm{I} 7 \mathrm{~h} \text { and } \\
\text { reduction with sodium borohydride (iv) }\end{array}$ & $\begin{array}{r}75 \\
200 \\
200\end{array}$ \\
\hline Fetuin & $\begin{array}{l}\text { After removal of neuraminic acid (i) } \\
\text { After removal of neuraminic acid and } \\
\text { galactose (iv) }\end{array}$ & $\begin{array}{l}250 \\
375\end{array}$ \\
\hline
\end{tabular}

( $7 \mathrm{mg}$ from I $15 \mathrm{mg}$ of PSM) which was excluded on Sephadex $\mathrm{G}_{50}$, had a high extinction at $230 \mathrm{~nm}$, but only traces of neuraminic acid or sugar. This is the (somewhat degraded) peptide portion of the glycoprotein and neither it nor the separated oligosaccharide fraction was inhibitory.

\section{Haemagglutination-reaction inhibitory activity of sow colostrum and colostral fractions}

Inhibitory activity was present in all $\mathrm{I} 2$ samples of colostrum tested. The inhibitory titre was not correlated with either parity of the sow or the presence of precipitins against the K88 preparation. Indeed, the most active sample lacked detectable precipitins.

Seven fractions, designated A to $G$, were normally isolated from colostrum on a Sephadex G200 column (Fig. I). The first four were probably analogous to those reported by Kessler \& Brew (1970). Three further retarded fractions which were anthrone positive were eluted with and after the $\beta$-lactoglobulin peak. The peak denoted A (Fig. I) was characterized as, in the main, porcine $\gamma$-globulin by electrophoresis (Davis, 1964) and by immunodiffusion (Ouchterlony, I964) against specific anti-porcine $\gamma$-globulin (kindly supplied by Dr J. M. Rutter, Compton).

In Fig. 2 are shown typical disc electrophoretic patterns for fractions $A$ to $F$ from the first gel-filtration fractionation of crude colostral whey. Porcine serum is also shown. The results are consistent with those of Karlsson (I966). Only traces of $\beta$-lactoglobulin were found in the final fraction. In addition to inhibitory activity in fraction $\mathrm{A}$, which is probably associated 


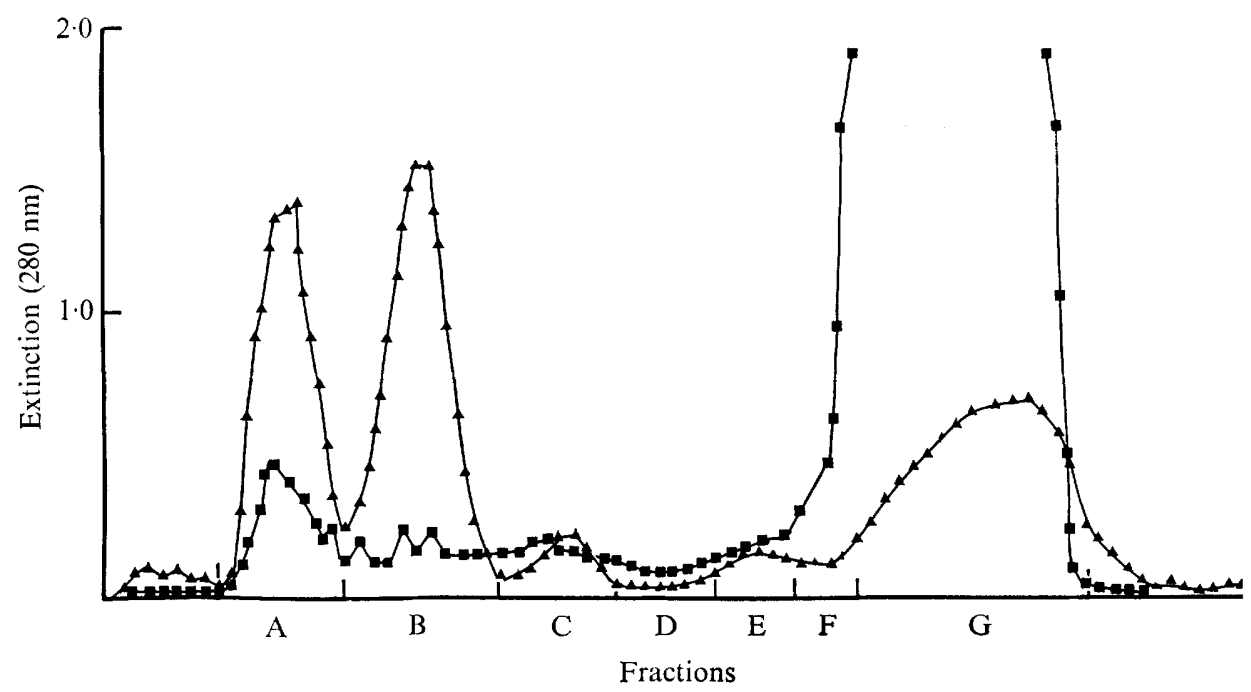

Fig. I. Elution diagram of porcine colostral whey. Sephadex G200; $4{ }^{\circ} \mathrm{C}$; solvent: 0.05 M acetate buffer $\mathrm{pH} 6.5,0.1 \%(\mathrm{w} / \mathrm{v})$ sodium azide. $\mathbf{\square}$, Carbohydrate (anthrone, arbitrary units); $\boldsymbol{\Lambda}$, extinction at $280 \mathrm{~nm}$. Fractions $\mathrm{A}$ to $\mathrm{G}$ are pools of regions shown.

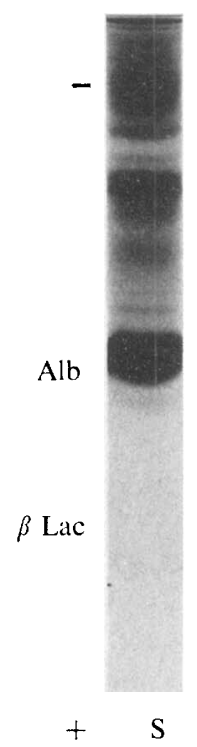

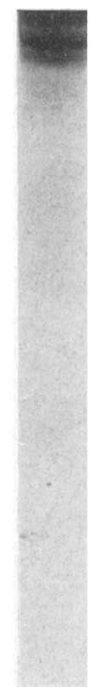

A

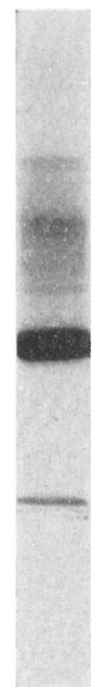

B

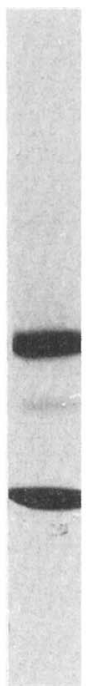

$\mathrm{C}$

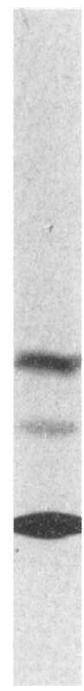

$\mathrm{D}$

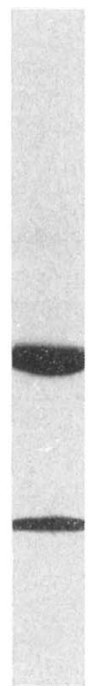

$\mathrm{E}$

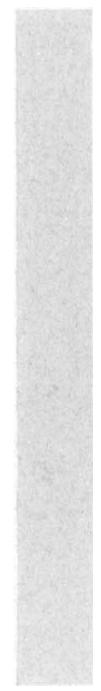

$\mathrm{F}$

Fig. 2. Gel electrophoretograms (Davis, 1964) of fractions designated in Fig. I (discontinuous system, running $\mathrm{pH} 9.5$ ). Nigrosin stain. Alb, serum albumin; $\beta$ lac, $\beta$ lactoglobulin.

with immune globulin, there was weak activity in fractions $\mathrm{E}$ and $\mathrm{F}$ (Table 4). Fraction $\mathrm{G}$ was almost pure lactose, although both $\mathrm{E}$ and $\mathrm{F}$ were contaminated with this sugar. These two fractions could be purified on Sephadex G25 and Gio columns to yield a nearly pure fraction of neuramin-lactose (Fig. 3). Its identity was confirmed by (i) hydrolysis, identification and quantitation of glucose and galactose on amberlite columns (Kessler, 1967); (ii) comparison of its elution volume, without prior hydrolysis, on the same column with that of authentic neuramin-lactose (Sigma) [the latter contained both the $2 \rightarrow 3$ and $2 \rightarrow 6$ neuramin- 


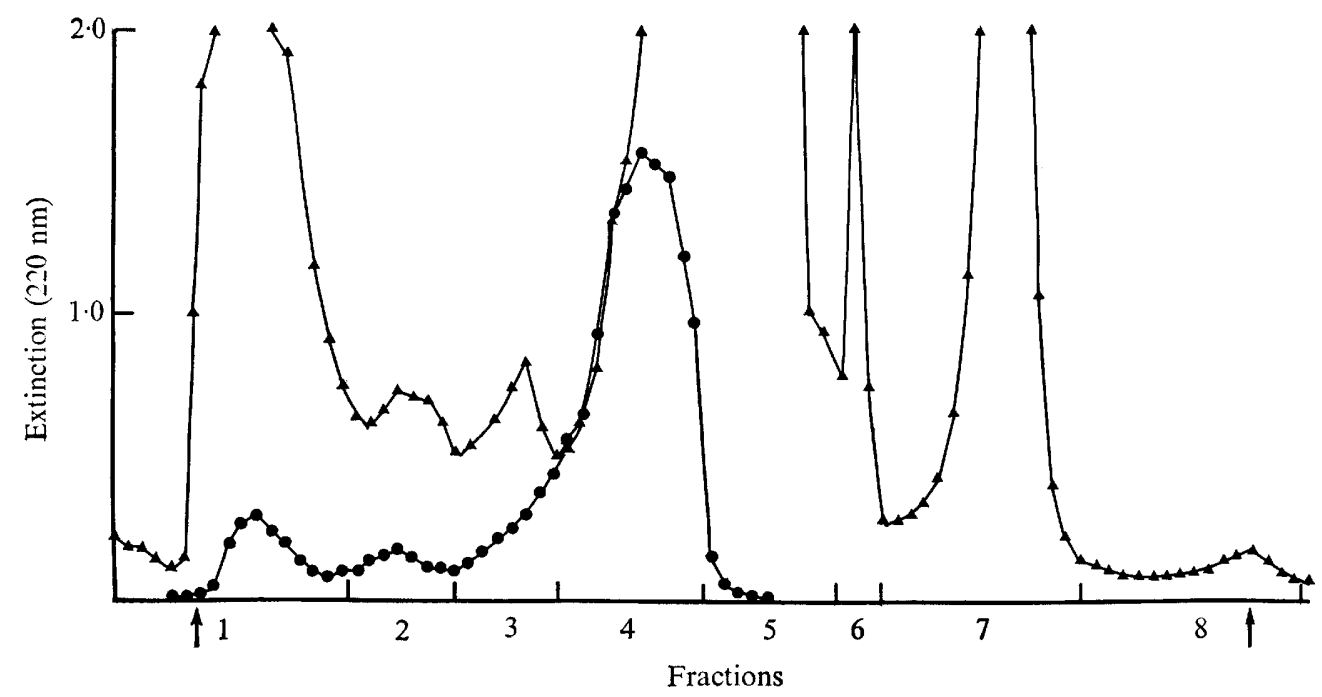

Fig. 3. Elution diagram of glycopeptide and oligosaccharide fractions of porcine colostrum. Biogel $\mathbf{P}_{4}$; room temperature; solvent: water saturated with chloroform. $\mathbf{0}$, Neuraminic acid (arbitrary units); $\boldsymbol{\Delta}$, extinction at $220 \mathrm{~nm}$. Positions of void and included volumes are indicated by arrows. Fractions I to 8 are pools of regions shown.

\section{Table 4. Haemagglutination inhibition by colostrum fractions}

Values are the lowest concentrations $(\mu \mathrm{g} / \mathrm{ml})$ of colostrum fractions from Sephadex G200 column (see Figs $I$ and 2) and from the oligosaccharide-rich fractions of colostrum obtained by the method of Öhman \& Hygstedt (1968) and fractionated on Biogel P4 (see Fig. 3) which inhibited the agglutination at $4{ }^{\circ} \mathrm{C}$ of an equal volume of a $3 \%$ suspension of guinea-pig red cells by 4 to 8 haemagglutinating doses of soluble K88 antigen from $E$. coli.

$\begin{array}{lr}\text { Fraction A } & 200 \\ \text { Fractions B, C, or D } & 5000 \\ \text { Fraction E } & 2500 \\ \text { Fraction F } & 2500 \\ \text { Fraction G } & 5000 \\ \text { Fractions E and F } & \\ \text { G25 excluded material } & 1000 \\ \text { G25 included material, } & \\ \text { pre-lactose fraction } & 2500 \\ \text { Fractions I and 2 } & 1000 \\ \text { Fraction 3 } & 2500 \\ \text { Fraction 4 } & \sim 10000\end{array}$

lactose (Kuhn \& Gauhe, I965) whereas our sample was almost entirely the $2 \rightarrow 3$ compound]: and (iii) by paper chromatography both of the trisaccharide and its hydrolysis products. Neuramin-lactose was not inhibitory in the HA reaction.

Deproteinized whey (from which all higher molecular weight materials, including immune globulins, had been removed) was fractionated on Biogel P4 (Fig. 3 and Table 5). Residual HA activity, not assignable to immune globulin, was found to be concentrated in fractions I and 2 which may be identified from their u.v. extinction and chemical analysis as glycopeptides. The third fraction is probably a mixture of tetra and higher oligosaccharides; it contained appreciable hexosamine, and the glucosamine:galactosamine ratio (Lee, Scocca \& Muir, 1969) was $2 \cdot 6: \mathrm{I}$. This fraction was an almost negligible proportion of the whole, however, and it too had low HA inhibitory activity. 


\section{Table 5. Chemical analysis of sow colostrum oligosaccharide fractions}

Compositions are expressed as \% (w/w); analytical methods are as given in Table 2.

$\begin{array}{cc}\text { Fraction* } & \text { Yield (mg) } \\ \text { I } & \text { I65 } \\ 2 & 120 \\ 3 & 4 \\ 4 & 283 \\ 5 & 577 \\ 6 & 2 \mathrm{I} 4 \\ 8 & \mathrm{I} \cdot 5\end{array}$

Hexose
3.4
$15 \cdot 7$
$51 \cdot 5$
$67 \cdot 3$
$121 \cdot 2$
108
3.05

Hexosamine
$2 \cdot 7$
$3 \cdot 8$
$24 \cdot 3$
$3 \cdot 7$
$1 \cdot 0$
0.5
$1 \cdot 25$

$\begin{array}{cr}\begin{array}{c}\text { Neuraminic } \\ \text { acid }\end{array} & \text { Fucose } \\ 2.6 & <0.2 \\ 3.0 & \sim 0.5 \\ >25 & 0 \\ >25 & 0 \\ 0 & 0 \\ \sim 0.2 & 0 \\ \sim 0.13 & 0\end{array}$

* $\mathrm{P}_{4} / 7$ was isolated in insufficient yield for analysis. Only fraction $\mathrm{P}_{4} / 8$ had an appreciable extinction at $254 \mathrm{~nm}$.

The remaining fractions were not pure, although some were subsequently purified by further column chromatography: in order of elution, they proved to be neuramin-lactose, lactose, glucose, an unidentified compound, and probably a nucleotide (Table 5).

\section{DISCUSSION}

Mucus glycoprotein from the pig intestine was inhibitory in the HA test, which implies that this substance contains the same structure as the intestinal receptor; the latter is known to be present on the brush border of the pig gut cell (R. Sellwood, unpublished). The intestinal mucus might therefore be expected to function as an inhibitor in vivo. To account for the fact that it evidently does not, the following mechanism is tentatively proposed. After adhering to the mucus gel layer overlying the intestinal epithelium, the organism can lyse the protective layer locally by virtue of a membrane-located protease which it possesses (Regnier \& Thang, I973). This would afford a passage for the organism through the mucus layer to the susceptible cell, to which the $\mathrm{K} 88$ antigen would then allow it to adhere. While this mechanism is hypothetical, it is based on a similar enzymic arrangement which allows spermatozoa to penetrate the mucus of the mammalian cervix (Gaddum \& Blandau, 1970; Blandau, 1973). Once adherence is established the bacterium is in a more favourable environment than that of the lumen of the gut; it can now proliferate and cause (if it also produces enterotoxins) disease.

The unsubstituted $\beta$-D-galactosyl residue appears to be an important feature of the structural chemical requirements of the binding site of the K88 adhesin. Removal of the terminal non-reducing fucosyl and $N$-acetyl galactosaminoyl residue from A substance - which would leave a terminal $\beta$-D-galactosyl residue - somewhat increases the inhibitory activity. The same procedure, however, applied to $\mathrm{H}$ substance will remove the terminal $\alpha$-L-fucosyl $\mathrm{I} \rightarrow 2 \beta$-D-galactosyl residue leaving, as the terminal sugar, a $\beta$-D- $N$-acetylglucosaminoyl residue (Morgan \& Watkins, 1969). This reduces the HA inhibition. The further observation that removal of the terminal neuraminic acid from fetuin makes this glycoprotein inhibitory would tend to confirm the importance of $\beta$-D-galactosyl since the modification exposes an unsubstituted $\beta$-D-galactosyl residue. This linkage is also present, though not predominant, in pig submaxillary glycoprotein (Carlson, I968), the most potent inhibitor found. It is probably present also in pig intestinal glycoprotein in both the $\mathrm{H}$ and $\mathrm{AH}$ active phenotypes. On the other hand, it cannot be asserted that there is any correlation between the amount of terminal $\beta$-D-galactosyl residue present and the inhibition titres. Moreover, sheep submaxillary glycoprotein, a very active inhibitor, is almost devoid of galactose (Table 2). 
Further, the sample of fetuin from which the terminal neuraminic acid residue had been cleaved suffered some reduction in its inhibitory activity when treated to remove the subterminal galactose residue, but the activity was not abolished.

All the most potent inhibitors, the submaxillary glycoproteins, are characterized by a predominant terminal neuraminic acid residue. The results do not indicate that this residue is involved in specific combination with $\mathrm{K} 88$. The removal of $>80 \%$ of the terminal neuraminic acid caused only a two- to three-fold decrease in activity. As already stated, fetuin causes inhibition only after neuraminic acid has been removed, which suggests that in this substance neuraminic acid actually blocks the inhibitory site.

Very approximately, the haemagglutination inhibition titre of the submaxillary gland glycoproteins decreases at the same rate as carbohydrate is removed (Tables 2 and 3). PSM, the most inhibitory glycoprotein, differs from OSM and BSM in that the terminal residue is $N$-glycolloyl- rather than $N$-acetylneuraminic acid. Bovine cervical glycoprotein which also possesses $N$-glycolloylneuraminic acid was a relatively weak inhibitor. The substitution of glycolloyl for acetyl in the terminal neuraminic acid is unlikely to be a determinant factor in the requirements of the $\mathrm{K} 88$ combining site.

Considering the non-immunoglobulin material in sow colostrum, our experiments have failed to demonstrate that the non-lactose oligosaccharides inhibit K88-mediated HA to any great extent. Our new data on the composition of pig colostrum show that, like the cow, the major non-lactose sugar is neuramin-lactose (Table 5) and the higher oligosaccharides are present in rather minor amounts. Fucose-containing oligosaccharides appear to be almost absent. Evidence for the occurrence of both small nucleotides, as in cow colostrum (Kieffer, Solms \& Egli, 1964) and of glycopeptide as in man (Vignati et al. 1968; Nichols \& Bezkorovainy, 1973) and cow (Kuhn \& Ekong, 1963) was also found; this latter fraction contained most of the rather weak inhibitory activity of colostrum referable to the nonimmunoglobulin material (Table 4). This ability to combine with $\mathrm{K} 88$, although weak, could influence the initial stages of colonization of the intestine by small numbers of enteropathogenic $E$. coli when even a slight reduction in, or interference with these molecular interactions may be sufficient to tip the balance in favour of the other protective mechanisms which undoubtedly function in the gut.

Our results are unfortunately less clear-cut than those which led to the identification of the influenza virus receptor by a similar approach (Gottschalk, Belyavin \& Biddle, I972). There are a number of factors bearing on this point which should be considered. The virus receptor is an $N$-acetylneuraminidyl residue, which is invariably terminal in a heterosaccharide sidechain, whereas the $\beta$-D-galactosyl residue normally is not. As a result of 'microheterogeneity' (Montgomery, 1972), there are always some incomplete sugar chains present in a complex glycoprotein, on some of which the relevant terminal $\beta$-D-galactosyl residue will be present. This is well shown in the case of the blood-group substance heterosaccharides (Rovis $e t$ al. 1973). We thus have a situation where the stepwise removal of an active terminal residue from one heterosaccharide side chain occurs concomitantly with the exposure of a subterminal $\beta$-D-galactosyl residue in another side chain; comparison of Tables I and 3 shows many instances where the selective removal of a terminal saccharide from a glycoprotein enhances or reduces activity, but few in which activity is completely abolished. On the other hand, the complete inactivity of the heterosaccharide side chains from pig submaxillary mucin cleaved by a technique which does not change the sugar chain structure except in the region where it originally adjoined the polypeptide moiety, suggests that a minimum molecular size is required and also, possibly, that other more stringent stereochemical requirements exist. 
Finally, the lack of a $\beta$-D-galactosyl structure in one of the inhibitory glycoproteins studied probably indicates that there is a degree of non-specific interaction between $\mathrm{K} 88$ antigen and the complex, high molecular weight glycoproteins which are found in mucus secretions. The fact that this was detected may be a reflection of the relative weakness of the $\mathrm{HA}$ reaction compared with the reaction between $\mathrm{K} 88$ and the intestinal cell.

The human $\mathrm{A}$ and $\mathrm{H}$ substances and the methyl glycosides listed in Table I were the kind gift of Professor W. M. Watkins.

\section{REFERENCES}

Aminoff, D., Morrow, M. \& Zarafonetis, C. J. D. (1964). Hog salivary glycoproteins and blood-group activation (abstr.). Federation Proceedings 23, 274.

ARBUCKLE, J. B. R. (1970). The location of Escherichia coli in the pig intestine. Journal of Medical Microbiology 3, 333-340.

BAIG, M. M. \& AMINOFF, D. (1973). Glycoproteins and blood-group activity. I. Oligosaccharides of serologically inactive hog submaxillary glycoproteins. Journal of Biological Chemistry 247, 6I I I-6I I 8.

Bertolini, M. \& Pigman, W. (1970). The existence of oligosaccharides in bovine and ovine submaxillary mucins. Carbohydrate Research 14, 53-63.

BLANDAu, R. J. (1973). Sperm transport through the mammalian cervix. In The Biology of the Cervix, pp. 285-304. Edited by R. L. Blandau and K. S. Moghissi. Chicago: University of Chicago Press.

BRANDEnburg, A. C. \& Wilson, M. R. (1973). Immunity to Escherichia coli in pigs: IgG immunoglobulin in passive immunity to E. coli enteritis. Immunology 24, I19-127.

CARLSON, D. M. (I968). Structures and immunochemical properties of oligosaccharides isolated from pig submaxillary mucins. Journal of Biological Chemistry 243, 616-626.

Chadwick, D. W., Smith, H., Annison, E. F. \& Morgan, W. T. J. (1949). Serological characters of hog gastric mucin. Nature, London $164,6 \mathrm{I}-62$.

Davis, B. J. (1964). Disc electrophoresis. II. Method and application to human serum proteins. Annals of the New York Academy of Sciences 121, 404-427.

Fischer, F. G. \& Nebel, H. J. (1955). Nachweis und Bestimmung von Glucosamin und Galactosamin auf Papierchromatogrammen. Hoppe-Seyler's Zeitschrift für physiologische Chemie 302, 10-19.

Gaddum, P. \& Blandau, R. J. (1970). Proteolytic reaction of mammalian spermatozoa. Science, New York 170, 749-75I.

GibBons, M. N. (1955). The determination of methylpentoses. Analyst 80, 268-276.

GibBons, R. A. (I963). The sensitivity of the neuraminosidic linkage in mucosubstances toward acid and toward neuraminidase. Biochemical Journal 89, 380-39I.

Gibbons, R. A., Dixon, S. N. \& Pocock, D. H. (1973). A new general method for the assessment of the molecular weight distribution of polydisperse preparations. Biochemical Journal 135, 649-653.

Gibbons, R. A., Morgan, W. T. J. \& GibBons, M. N. (I955). The isolation of blood-group active mucoids from ovarian cyst fluids. Biochemical Journal 6o, 428-436.

Gibbons, R. A. \& Sellwood, R. (1973). The macromolecular biochemistry of cervical secretions. In The Biology of the Cervix, pp. 25I-265. Edited by R. J. Blandau and K. S. Moghissi. Chicago: University of Chicago Press.

GottschalK, A., Belyavin, G. \& Biddle, F. (1972). Glycoproteins as influenza virus haemagglutinin inhibitors and as cellular virus receptors. In Glycoproteins, vol. B, 2nd edn, pp. 1082-1096. Edited by A. Gottschalk. Amsterdam: Elsevier.

GrimmonPreZ, L. (1971). Les glucides du lait. Annales de la nutrition et de l'alimentation 25, A39-A79.

Gyorgy, P., Norris, R.F. \& Rose, C.S. (1954). Bifidus factor I. A variant of Lactobacillus bifidus requiring a special growth factor. Archives of Biochemistry and Biophysics 48, 193-202.

Hakomori, S. \& Jeanloz, R. W. (I970). Glycolipids as membrane antigens. In Blood and Tissue Antigens, pp. I49-16I. Edited by David Aminoff. New York: Academic Press.

HEIMER, R. (1957). Sialic acid-containing compounds, their degradation and the structure of sialic acid. Doctoral dissertation, Columbia University, New York.

Heimer, R. \& Meyer, K. (1956). Studies on the sialic acid of submaxillary mucoid. Proceedings of the National Academy of Sciences of the United States of America 42, 723-734.

HUANG, R. T. C. (197I). The structures of some neuraminic acid-containing oligosaccharides of human milk. Hoppe-Seyler's Zeitschrift für physiologische Chemie 352, 1645-1652. 
JONES, G. W. (1972). The adhesive qualities of K88 antigen of strains of Escherichia coli pathogenic to neonatal pigs. Ph.D. Thesis, University of Reading.

Jones, G. W. \& RuTTER, J. M. (1972). Role of the K88 antigen in the pathogenesis of neonatal diarrhoea caused by Escherichia coli in piglets. Infection and Immunity 6, 918-927.

JONES, G. W. \& RUTTER, J. M. (I 974). The association of K88 antigen with haemagglutinin activity in porcine strains of Escherichia coli. Journal of General Microbiology 84, I35-144.

KARLSSON, B. W. (I966). Immunoelectrophoretic studies on relationships between proteins of porcine colostrum, milk and blood serum. Acta pathologica et microbiologica scandinavica 67, 83-IOI.

KenNY, J. F., WeINERT, D. W. \& Gray, J. A. (I974). Enteric infection with Escherichia coli 0127 in the mouse. II. Failure of specific immunity to alter intestinal colonisation of infants and adults. Journal of Infectious Diseases 129, 10-20.

KESSLER, R. B. (1967). Rapid quantitative ion exchange chromatography of carbohydrates. Analytical Chemistry 39, 1416-1422 (see also Technicon Bulletin, No. 124).

Kessler, E. \& Brew, K. (I970). The whey proteins of pigs' milk. Isolation and characterisation of a $\beta$ lactoglobulin. Biochimica et biophysica acta 200, 449-458.

KiefFer, F., Solms, J. \& EgLI, R. H. (I964). Vorkommen von Nucleotiden und verwandten Verbindungen in Milch und Milchprodukten. Zeitschrift für Lebensmitteluntersuchung und Forschung 125, 346-350.

KobATA, A. \& Ginsberg, V. A. (1972a). Oligosaccharides of human milk. III. Isolation and characterisation of a new hexosaccharide, lacto- $N$-hexose. Journal of Biological Chemistry 247, $1525-2529$.

Kobata, A. \& Gnsberg, V. A. (1972 $b$ ). Oligosaccharides of human milk. IV. Isolation and characterisation of a new hexosaccharide, lacto- $N$-neo-hexose. Archives of Biochemistry and Biophysics $\mathbf{1 5 0}, 273-28 \mathrm{I}$.

KoHLER, E. M. \& BoHL, E. H. (1966). Studies of Escherichia coli in gnotobiotic piglets. III. Evaluation of orally administered specific antisera. Canadian Journal of Comparative Medicine 30, 233-237.

Kuhn, R. \& Ekong, D. (I963). Über ein Glykopeptid aus Kuh-Colostrum. Chemische Berichte 96, 683-688.

Kunn, R. \& Gauhe, A. (1962a). Über drei saure Penta-Saccharide aus Frauenmilch. Chemische Berichte 95 , $5 \mathrm{I} 3-5 \mathrm{I} 8$.

Kuhn, R. \& Gauhe, A. (I962 b). Die Konstitution der Lacto- $N$-Neotetraose. Chemische Berichte 95, 51 8-522.

KunN, R. \& GAUHE, A. (1965). Bestimmung der Bindungstelle von Sialinsäureresten in Oligosacchariden mit Hilfe von Perjodat. Chemische Berichte 98, 395-4I 3.

LEE, Y. C., SCOCCA, J. R. \& MUIR, L. (1969). Rapid automatic analysis of sugar components in glycoproteins. Analytical Biochemistry 27, 559-566.

MCGuire, E. J. (1970). Biosynthesis of submaxillary mucins. In Blood and Tissue Antigens, pp. 46I-478. Edited by David Aminoff. New York: Academic Press.

Messer, M. \& Kerry, K. R. (1973). Milk carbohydrates of the echidna and the platypus. Science, New York I80, 20I-203.

Miniats, O. P., Mitchell, L. \& Barnum, D. A. (1970). Response of gnotobiotic piglets to Escherichia coli. Canadian Journal of Comparative Medicine 34, 269-276.

MONTGOMERY, R. (1972). Heterogeneity of the carbohydrate groups in glycoproteins. In Glycoproteins, vol. A, 2nd edn, pp. 518-529. Edited by A. Gottschalk. Amsterdam: Elsevier.

Morgan, W. T. J. \& Watkins, W. M. (1969). Genetic and biochemical aspects of human blood group A, B, H, Le and Le ${ }^{\mathrm{b}}$ specificity. British Medical Bulletin 35, 30-34.

Nichols, J. H. \& Bezkorovainy, A. (I973). Isolation and characterisation of a glycoprotein from human colostrum. Biochemical Journal 135, 875-880.

Öhman, R. \& Hygstedt, O. (I968). The isolation of sialyllactoses with the aid of gel filtration. Analytical Biochemistry 23, 391-402.

OuCHTERLONY, O. (I964). Gel diffusion techniques. In Immunological Methods, pp. 55-78. Edited by J. F. Ackroyd. Oxford: Blackwell.

Regnier, P. \& Thang, M. N. (I973). Membrane associated proteases in E. coli. FEBS Letters 36, 3 I-33.

Rondle, C. J. M. \& Morgan, W. T. J. (I955). The determination of glucosamine and galactosamine. Biochemical Journal 61, 586-589.

Rovis, L., Anderson, B., Kabat, E. A., Gruezo, F. \& Liao, J. (I973). Heterogeneity of carbohydrate fragments isolated from human blood group $\mathrm{H}$ and $\mathrm{Le}^{\mathrm{a}}$ active glycoproteins by base-borohydride degradation. Biochemistry 12, 1955-1961.

Rutter, J. M. \& Jones, G. W. (1973). Protection against enteric disease caused by Escherichia coli - a model for vaccination with a virulence determinant. Nature, London 242, 53 I-532.

SCHÖNFELD, H. (1927). Über die Beziehungen der einzelnen Bestandteile der Frauenmilch zur Bifidusflora. Jahrbuch der Kinderheilkunde $\mathbf{1} 3$, 19-60. 
SLOMIANY, B. L. \& MEYeR, K. (1973). Oligosaccharides produced by acetolysis of blood-group (A+H) sulfated glycoproteins from hog gastric mucin. Journal of Biological Chemistry 248, 2290-2295.

Sмiтh, H.W. (1972). The nature of the protective effect of antisera against Escherichia coli diarrhoea in piglets. Journal of Medical Microbiology 5, 345-352.

Smith, H. W. \& LingGood, M. A. (1972). Further observations on Escherichia coli enterotoxins with particular regard to those produced by atypical piglet strains and by calf and lamb strains. The transmissible nature of these enterotoxins and of a $\mathrm{K}$ antigen possessed by calf and lamb strains. Journal of Medical Microbiology 5, 243-250.

SmIth, F. \& UNRAU, A. M. (1959). On the presence of $\mathrm{I} \rightarrow 6$ linkages in laminarin. Chemistry and Industry, $88 \mathrm{I}-882$.

SoJKA, W. J. (197I). Enteric diseases in new-born piglets. Veterinary Bulletin 4I, 509-522.

SVENNERHOLM, L. (1957). Quantitative estimation of sialic acids. II. A colorimetric resorcinol hydrochloric acid method. Biochimica et biophysica acta 24, 604-611.

Vignati, E., Sassi, A., Penati, M. R., Formica, U. \& Marconi, M. (i968). Studio di una componente glicopeptidica del colostro umano. Bollettino della Società italiana di biologia sperimentale 45, I05-107.

WARREN, L. (1959). The thiobarbituric acid assay of sialic acids. Journal of Biological Chemistry 234, 19711975.

Watkins, W. M. (1972). Blood group substances. In Glycoproteins, vol. B, 2nd edn, pp. 830-89i. Edited by A. Gottschalk. Amsterdam: Elsevier.

WATKIns, W. M. \& Morgan, W. T. J. (I962a). Specific inhibition studies relating to the Lewis blood-group system. Nature, London I80, I038-1040.

WatKIns, W. M. \& MoRGAN, W. T. J. (I962b). Further observations on the inhibition of blood-group specific serological reactions by simple sugars of known structure. Vox sanguinis 7, 129-150.

Wilson, M. R., GyLeS, C. L. \& SVENDSEN, J. (I97I). Immunity to Escherichia coli in pigs: anti-enterotoxin in colostrum and serum from vaccinated and non-vaccinated sows. Canadian Journal of Comparative Medicine 30, 233-237.

WOLFROM, M. L. \& MilleR, J. B. (1956). The detection of carbohydrates on paper chromatograms. Analytical Chemistry 28, 1037.

Yemm, E.W. \& Willis, A. J. (1954). The estimation of carbohydrates in plant extracts by anthrone. Biochemical Journal 57, 508-514. 